\title{
THE LEVEL OF USE OF INFORMATION AND COMMUNICATION TECHNOLOGY AT VOCATIONAL HIGH SCHOOL
}

\author{
Purnamawati \\ Universitas Negeri Makassar \\ Anas Arfandi \\ Universitas Negeri Makassar \\ Nurfaeda \\ Universitas Negeri Makassar
}

\begin{abstract}
Learning in the 4.0 era uses the concept of 4 C (Communication, Collaboration, Critical Thinking, and Problem Solving, Creativity, and Innovation). This concept is linear to the use of information and communication technology (ICT). Technology literacy is involved in all subjects of learning. This phenomenon triggers the teachers, the students, and the school environment to play an active role so that technological progress has meaningfulness in increasing student competence. This study aims to: (1) describe the level of the use of ICT use, (2) determine the factors that influence the use of ICT, and (3) describe the ability of teachers to use ICT in the learning process. This research is a mixed-method with a sequential explanatory strategy. The data collected use questionnaires, interviews, observations, and documentation. The results obtained: (1) the level of ICT utilization in the learning process is at level 4, which means Managed and Measurable. (2) the factors that influence the use of ICT in the learning process in Makassar City Vocational High School based on the Resiliency Maturity Assessment Framework screen components namely data application factors, and (3) the ability teachers in utilizing ICTs in the learning process at Vocational High School in Makassar City meet the criteria very well.
\end{abstract}

Keywords: ICT utilization, resiliency maturity assessment framework (RMAF), capability maturity model (CMM), vocational high school (SMK)

Permalink: http://dx.doi.org/10.21831/jpv.v9i3.27117

Contact Purnamawati هurnamawati@unm.ac.id

-Department of Electronics Engineering Education Universitas Negeri Makassar Kampus II Parangtambung, Jl. Daeng Tata Raya, Gedung EK Fakultas Teknik, Tamalate, Kota Makassar, Sulawesi Selatan 90224, Indonesia 


\section{INTRODUCTION}

The progress of information, communication, and technology (ICT) provide opportunities in education by developing learning and training models through the use of advanced ICT. It is intended to find solutions to overcome the weaknesses of the learning process. In the aspect of culture and work attitude, ICT can change employees' performance: workers who initially worked paper-based are switched to working on a digital basis. Their discipline in working is no longer based on entry hours, but it is assessed based on their performance (Ahmad, 2018). Thus, the era of the industrial revolution 4.0 provides new experiences for educators in improving graduate competencies.

The industrial revolution 4.0 continues to advance into a new civilization in the development of Information, Communication, and Technology (ICT). It affects all components, including education in Indonesia. This era has an impact on the necessity of changes in learning patterns in schools that were still traditionally paper-based to be ICT-based.

The presence of ICT in education has an impact on the realization of a learning activity that is active, fun, and encourages students to be actively involved. The integrity of ICT in delivering messages is very significant. ICT in education has changed the paradigm of providing subject matter to students. One example of the use of ICT in education is the use of computers/laptops, internet networks, and also smartphones as sources or learning media.

The existence of facilities and infrastructure plays an essential role in the application of ICT-based learning. Regulation of the Minister of National Education No. 19 of 2005, on National Standard of Education explains that facilities and infrastructure are the national education standards related to the minimum criteria of learning spaces, places to exercise, places of worship, libraries, laboratories, workshops, playgrounds, places of creation and recreation, and other learning resources, needed to support the learning process, including the use of information and communication technology. It shows that the provision of facilities and infrastructure to support the use of ICT is now a standard requirement. The utilization of ICT in the learning process, as well as the application of ICT in learning, has become a standard that must be implemented by each school.
For the educational system, ICT is useful for providing a quality education which is in line with constructivism as a contemporary learning paradigm (Lamanauskas, 2008). Besides, teacher preparation equipped with ICT tools and facilities is one of the main factors in the success of technology-based teaching and learning (Deebom \& Zite, 2016; Eady \& Lockyer, 2013; Ghavifekr \& Rosdy, 2015; Mas'ud \& Surjono, 2018; Sangrà \& GonzálezSanmamed, 2010). The outcome of the learning is to improve the quality of graduates who can compete in advanced tertiary education or globally in the industrial world. One example of the use of ICT facilities and infrastructure in learning is e-learning.

Moreover, Hanum (2013) outlines the need for better preparation to implement elearning. E-Learning, which is prepared better, is more effective, and students can own working skills in preparing graduates of Vocational High School (Sekolah Menengah Kejuruan or SMK) who are ready to work and have expertise in technology and information by using e-learning.

A survey in the Department of Computer and Network Engineering (Teknik Komputer Jaringan or TKJ) in the vocational high school indicates that the average aspects of ICT management are adequate $(40-60 \%)$. This value indicates that the awareness of the importance of ICT infrastructure to support the TKJ Department in Malang is very good (Elmunsyah, 2014).

Digital learning resources support information processing by helping students to develop mental representations through a mixture of media elements presented to them. Digital learning resources include content and, sometimes, learning activities. They combine multimedia elements, including text, images, video, and audio, to present information (Eady \& Lockyer, 2013; Mas'ud \& Surjono, 2018; Rahim, 2016).

In addition, Vernanda, Abdullah, and Rohendi (2018) analyze internet literacy for vocational teachers using six indicators, namely (1) availability of internet access tools, (2) location of internet access, (3) location of internet access and intensity of internet access, (4) internet utilization in education, (5) use of the internet for social media, and (6) use of the internet for research, and for sharing knowledge and information. The level of internet 
literacy maturity of vocational education teachers has reached level 2, which means that vocational teachers have used the internet many times to help them with their daily activities and have a repetition pattern in term of internet utilization.

The uses of ICT in learning namely: (1) Utilizing multimedia facilities already available to facilitate activities carried out during the learning process, (2) Utilizing the internet for the distance learning process (virtual classrooms) (3) students can demonstrate with existing multimedia devices (Ab Hadi, Mohamad, \& Jaafar, 2010; Rusman, Kurniawan, \& Riyana, 2011). This statement, according to the opinion of Supiandi and Lisa (2018), ICT can be applied innovatively at all stages of learning activities teaching, starting from making lesson plans, preparing materials, presenting materials, applying lessons, to evaluating. The use of ICT, school management, and education personnel in schools can improve school administration and efficient information flow to support the achievement of educational standards and the process of decentralization of education in Indonesia.

On the preliminary observations at SMK in Makassar, teachers use a computer-based learning approach in the teaching and learning process. Every classroom has installed ICT devices, such as LCD, projectors, and audio systems. The urgency of this research is to find out how far the ICT-based learning has been implemented in SMK.

\section{RESEARCH METHOD}

The method comprises of the design of the research, population, and sample, sampling techniques, procedures, instruments (including the construct, validity, and reliability), data collection tools, and data analysis techniques. This type of research is a mixed methods research, which is a step of study by combining two forms of approach in research, namely qualitative and quantitative.

The research was conducted at five public Vocational High Schools (Sekolah Menengah Kejuruan Negeri or SMKN) in Makassar City, namely: SMK 2, SMK 3, SMK 4, SMK 5, and SMK 7. Those schools provide study programs of Computer and Network Engineering Study Program (Teknik Komputer dan Jaringan or TKJ), Software Engineering
(Rekayasa Perangkat Lunak or RPL), Animation, and Multimedia. The instruments used in the research are observation, interviews, and questionnaires. The research subjects are the school principals, heads of department, ICT productive teachers, and students of the ICT department.

Resilience Maturity Assessment Framework (RMAF) was used in analyzing the research data. RMAF is one of the models and evaluations to measure the level of ICT utilization in terms of technology, application, data, personal as well as process usage. An approach that can be used to see the level of ICT use in education is the Capability Maturity Model (CMM) approach. RMAF is one of the frameworks for evaluating the maturity of ICT services in an organization (Bhamidipaty, Lotlikar, \& Banavar, 2007).

RMAF has six key screens to determine the maturity level of ICT services in a school, such as a strategy, individual/group, process, application and data, technology, and facilities. Furthermore, it explained that the implementation of each RMAF main screen in schools is: (1) Facilities, (2) Technology, (3) Applications and Data, (4) Processes, and (5) Personal/ Organization.

Furthermore, CMM analysis was used to determine the ICT maturity model. A maturity model (capability) is a process that can help define and understand the processes of an organization. In the case of the Maturity Model maturity scale, according to Kumta and Shah (2002), there are five levels/scale of maturity, namely:

\section{Scale 1: Initial}

This scale has begun to recognize the process of information technology in the company. However, there is no standardization done individually and not organized. The overall management approach is still not established.

\section{Scale 2: Repeatable but Intuitive}

This scale has started to have procedures in the information technology process. However, there is no formal research and communication about standard procedures. The individual still bears responsibility for the process, and the level of dependence on the ability of individuals is considerable so that errors occur. 


\section{Scale 3: Defined Process}

Procedures at this scale are standardized, documented, and communicated through training. However, the implementation still depends on the individual, whether they want to follow the system or not. The procedure made is not complicated; only a formalization of existing technology.

\section{Scale 4: Managed and Measurable}

This scale can measure and monitor existing methods so that they are easily covered if deviations occur. The process is going well and is constant. Automatic and limited information technology devices are used.

\section{Scale 5: Optimized}

Existing processes at this scale have reached best practice through a process of continuous improvement. Information technol- ogy has been used and integrated to automate working processes within the company, improve quality, effectiveness, and adaptability to the company.

This study uses a qualitative descriptive analysis, referring to the Maturity Model Scale (Bhamidipaty et al., 2007; Carcary, 2013; Kumta \& Shah, 2002) for SMK as presented in Table 1 . To determine the maturity scale of ICT utilization using the Capability Maturity Model (CMM) scale based on the total score obtained, the following is a reference:

$\begin{array}{ll}\text { Total score: } & \\ 0.01-1.00 & \text { Level 1 } \\ 0.01-2.00 & \text { Level 2 } \\ 2.01-3.00 & \text { Level 3 } \\ 3.01-4.00 & \text { Level 4 } \\ 4.01-5.00 & \text { Level 5 }\end{array}$

Table 1.Scale Maturity Model in Vocational high School

\begin{tabular}{|c|c|c|}
\hline Scale Maturity & Description & $\begin{array}{c}\text { Attributes of Process and Academic } \\
\text { Management }\end{array}$ \\
\hline $\begin{array}{l}\text { LEVEL } 0 \\
\text { NOT EXISTENCE }\end{array}$ & $\begin{array}{l}\text { ICT is not utilized yet for the teaching and learning } \\
\text { process }\end{array}$ & \\
\hline $\begin{array}{l}\text { LEVEL } 1 \\
\text { INITIAL }\end{array}$ & $\begin{array}{l}\text { Schools have used ICT facilities in the teaching and } \\
\text { learning process in the classroom. ICT intended here is } \\
\text { the use of laptops and LCD projectors for teaching } \\
\text { activities using presentation programs. }\end{array}$ & $\begin{array}{l}\text { The use of ICT in the teaching and } \\
\text { learning process. }\end{array}$ \\
\hline $\begin{array}{l}\text { LEVEL } 2 \\
\text { REPEATABLE }\end{array}$ & $\begin{array}{l}\text { Schools have begun to set standards for ICT-based } \\
\text { learning procedures. The learning process has started } \\
\text { with audio, video, and animation (multimedia learning) } \\
\text { and taking the latest scientific references from the } \\
\text { internet (internet-based content). }\end{array}$ & $\begin{array}{l}\text { 1. Utilization of ICT as a repository } \\
\text { of knowledge. } \\
\text { 2. Utilization of ICT as a learning } \\
\text { tool. } \\
\text { 3. Utilization of ICT as an } \\
\text { educational facility in schools. }\end{array}$ \\
\hline $\begin{array}{l}\text { LEVEL } 3 \\
\text { DEFINED PROCESS }\end{array}$ & $\begin{array}{l}\text { Schools have established multimedia-based learning } \\
\text { standardization and the latest scientific reference from } \\
\text { the internet. Schools have started archiving the school } \\
\text { documents and managing school administration using the } \\
\text { application program. }\end{array}$ & $\begin{array}{l}\text { 1. } \begin{array}{l}\text { Multimedia-based learning } \\
\text { standard. }\end{array} \\
\text { 2. } \begin{array}{l}\text { Standardization of educational } \\
\text { documents. }\end{array}\end{array}$ \\
\hline $\begin{array}{l}\text { LEVEL } 4 \\
\text { MANAGED AND } \\
\text { MEASURABLE }\end{array}$ & $\begin{array}{l}\text { Schools have developed school management information } \\
\text { systems that integrate educational documents, and ICT- } \\
\text { based educational administration/management proc- } \\
\text { esses. The school management information system has } \\
\text { integrated modules of subject document databases, } \\
\text { curriculum management, personnel, student affairs, } \\
\text { finance, facilities, and infrastructure as well as } \\
\text { specialized services in schools. }\end{array}$ & $\begin{array}{l}\text { 1. Utilization of ICT as a school } \\
\text { management facility. }\end{array}$ \\
\hline $\begin{array}{l}\text { LEVEL } 5 \\
\text { OPTIMIZED }\end{array}$ & $\begin{array}{l}\text { Schools begin to optimize the school management } \\
\text { information system. The school management information } \\
\text { systems are developed according to the needs of schools } \\
\text { in the future. }\end{array}$ & $\begin{array}{l}\text { 1. Optimization of the use of ICT as a } \\
\text { school management facility and } \\
\text { teaching and learning facilities in } \\
\text { schools }\end{array}$ \\
\hline
\end{tabular}




\section{RESULTS AND DISCUSSION}

\section{Analysis of ICT Utilization in the Learning Process in Public Vocational High School in Makassar Using the Capability Maturity Model (CMM) Approach}

Based on the data obtained, the use of ICT in the learning process at SMKNs in Makassar City is at the level of 3.68. Based on the results of the analysis using the Capability Maturity Model (CMM) scale, the level of ICT utilization in the learning process at public vocational high schools in Makassar City is at level 4 (Managed and Measurable). The result of the analysis of maturity scale (Model Maturity Scale) of ICT utilization in public vocational high school in Makassar City is presented in Figure 1.
Figure 1 shows that SMKN 4 Makassar gets a dominant score from other schools that are the subject of research, while SMKN 3 Makassar has the lowest score. SMKN 4 and SMKN 7 Makassar reach the CMM level, SMKN 2 Makassar is at level 4, while SMKN 3 and SMKN 5 are at level 3.

Table 2 shows that based on the indicators of the use of ICT as a repository of knowledge, five SMKNs in Makassar City are at an average of 3.55, or at level 4 (Managed and Measurable). The indicators of the use of ICT as learning aids at five SMKNs in Makassar are at an average of 3.60 or level 4 (Managed and Measurable). The average value of the use of ICT as an educational facility in five SMKNs in Makassar City is at an average of 3.73 or is at level 4 (Managed and Measurable).

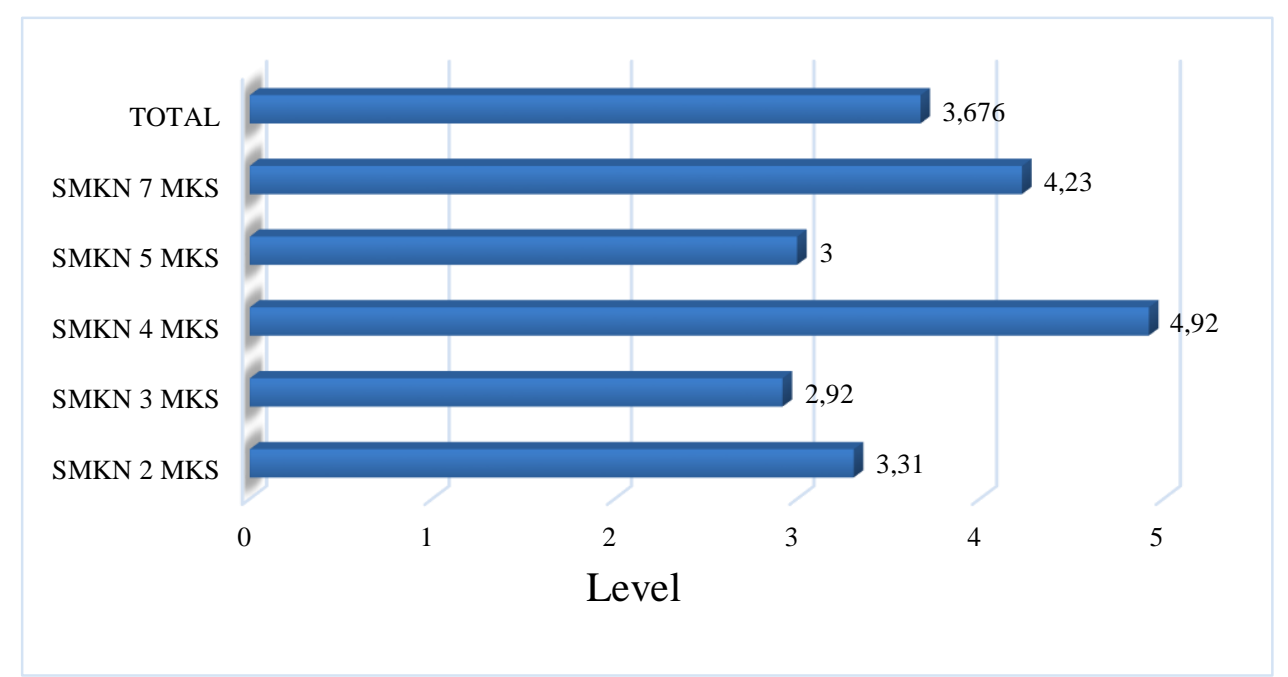

Figure 1. Graph of Utilizing ICT in the Learning Process at Vocational High School

Table 2. The ICT Utilization by the Capability Maturity Model

\begin{tabular}{rcccc}
\hline School & $\begin{array}{c}\text { ICT as a storehouse of } \\
\text { knowledge }\end{array}$ & ICT as learning resources & ICT as Education facilities & Average \\
\hline SMKN 2 & 3.00 & 3.00 & 4.00 & 3.33 \\
SMKN 3 & 2.50 & 2.67 & 2.67 & 2.61 \\
SMKN 4 & 4.75 & 5.00 & 5.00 & 4.92 \\
SMKN 5 & 2.75 & 3.33 & 3.00 & 3.03 \\
SMKN 7 & 4.75 & 4.00 & 4.00 & 4.25 \\
Average & 3.55 & 3.60 & 3.73 & 3.63 \\
\hline
\end{tabular}




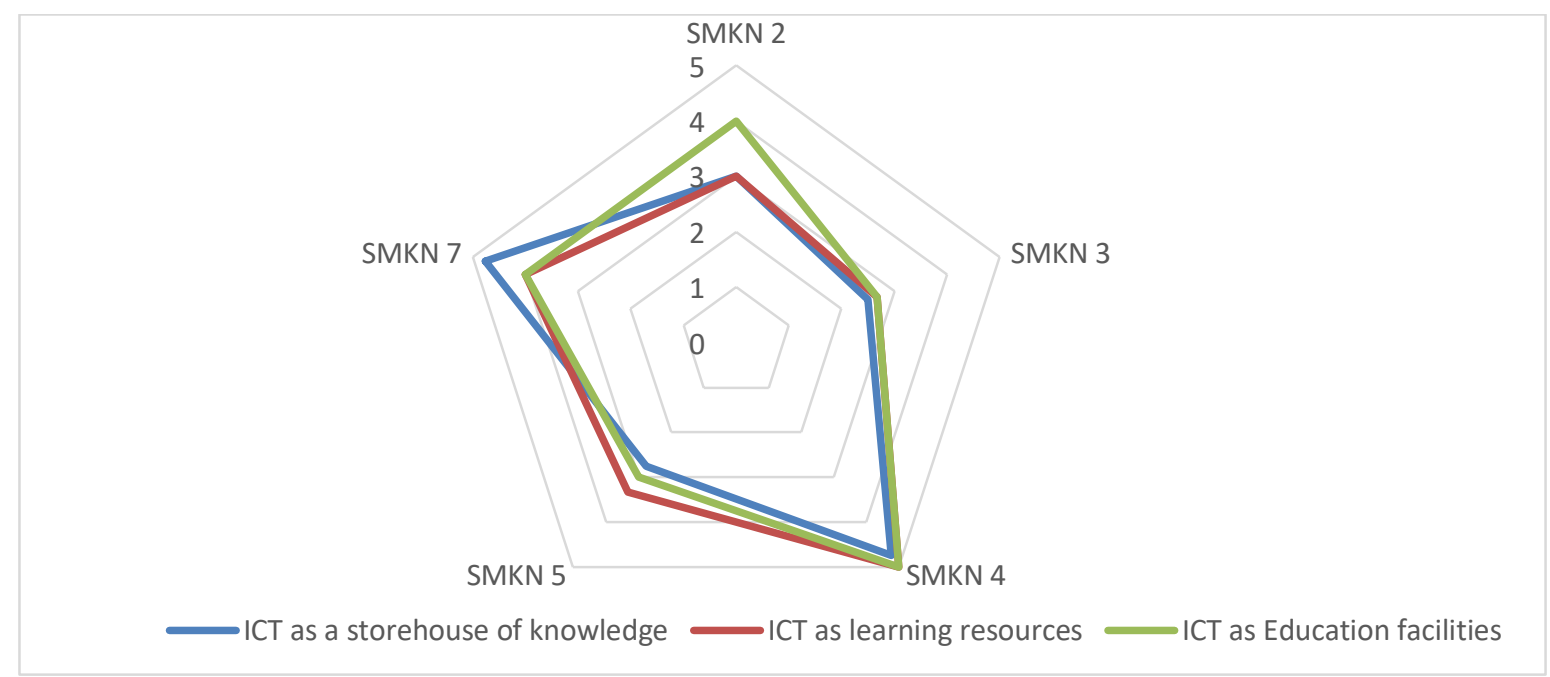

Figure 2. Graph of Each Indicator Variable

Figure 2 shows that public vocational high schools in Makassar City have used ICT as an educational facility. It is also strengthened from the results of interviews which reveal that SMKNs in Makassar have developed a school management information system that integrate educational documents, and also ICTbased educational administration/management processes. The school management information system has integrated modules of subject document databases, curriculum management, personnel, student affairs, finance, facilities, and infrastructure and specialized services at schools.

ICT-based education management information systems in new schools include (1) ICT as a science, (2) ICT as a learning aid, (3) ICT as an educational facility in schools (Sujoko, 2013, p. 72), while, the application of ICT in the field of education management refers to the Directorate of Secondary Education of the Ministry of National Education, covering: (1) ICT-based curriculum management, (2) ICTbased personnel management, (3) ICT-based student management, (4) ICT-based financial, (4) Management of preventive maintenance of ICT-based school facilities and infrastructure.

Based on previous researches, schools have begun to set standards for ICT-based learning procedures (Rahim, 2016; Sujoko, 2013; Supiandi \& Lisa, 2018). The learning process has already started with audio, video, and animation (multimedia learning) and taking the latest scientific references from the internet (internet-based content).
After obtaining data from the results of previous studies, it is concluded that the use of ICT in the learning process at SMKNs in Makassar has experienced a very high increase. It has been obtained research results on the use of ICT in the learning process at SMKNs in Makassar are at level 4 (Managed and Measurable).

Factors Influencing the Use of ICT in the Learning Process in SMKNs in Makassar Based on the Component of Resilience

Based on the data obtained, there are several components of RMAF that affect the use of ICT in the learning process in SMKNs in Makassar City, which are found on the third screen (application and data screen). On this screen, there is a school, namely SMK 3 Makassar, which is still minimal in utilizing application programs in the teaching and learning process due to hardware limitations such as LCD projectors in the classroom.

\section{Efforts to Apply ICT Utilization in Learning Processes in SMKNs in Makassar City}

The implementation of the learning program by utilizing information and communication technology certainly presents its challenges for schools to make optimal use of ICT in learning. Various steps to always improve both the competency of students and the professional competence of educators continue to be done, among others, an increase in developing learning materials that are taught more 
creatively so that a teacher must always follow the development of existing technology.

The efforts made by students in the application of ICT use in the learning process, based on the research findings, in SMKNs in Makassar are very good; namely, 4.27, and the percentage level is $92.85 \%$, which is very high. Meanwhile, the efforts made by the teacher in applying ICT in the learning process in SMKNs in Makassar City are in the very good category of 4.61, and the percentage level of $92.85 \%$ is very high.

Based on previous research conducted by Husain (2014), he suggested the use of ICT in learning at Muhammadiyah Tarakan High School. The teacher's paradigm, when utilizing ICT in learning, is still limited to the use of presentations, especially power points. The purpose of internet use is still limited to finding information about the material to be conveyed rather than being used as an integrated new learning system. Likewise, social networking is still not widely used as a new learning system to further enhance the effectiveness and efficiency of the learning process (Ghavifekr \& Rosdy, 2015; Hanum, 2013). The findings indicate that the majority of students exhibit higher motivation, learning skills, which is more significant in the assessment determined. Additional benefits are obtained when the teacher's work in planning and organizing teaching and learning sessions becomes more efficient. Findings show that individual students at Technical and Vocational Education and Training (TVET) can benefit from the integration of ICT into their learning (Yasak \& Alias, 2015).

\section{CONCLUSION}

The level of ICT use in the learning process at SMKNs in Makassar is at level 4. It is in the Managed and Measurable category, which is in 3.68 value. It means that SMKNs in Makassar City have developed a school management information layer that integrates the document layer, and the administrative process/layer management will be ICT-based. The school management information system has integrated the database modules of lesson documents, curriculum management, personnel, student affairs, finance, facilities, and infrastructure as well as specialized services in schools.
Factors that influence the use of ICT in the learning process at SMKNs in Makassar City are the data application layer, in which this layer has one school, namely SMK 3 Makassar which is still minimal in utilizing application programs in teaching and learning processes due to hardware limitations such as LCD projector in the classroom. Furthermore, the ability of teachers in the use of ICT in the learning process at SMKN in Makassar City is a Very Good criterion, with value of 4.61 and the percentage level is $92.85 \%$, which is in very high category. Meanwhile, the ability of students is in the very good criteria at 4.27 value, and the percentage level is $92.85 \%$ which is very high based on the percentage of research formulas.

\section{ACKNOWLEDGMENTS}

The authors express special gratitude to the Directorate of Research and Development of the Ministry of Research Technology and Higher Education of Indonesia, which funded this research.

\section{REFERENCES}

Ab Hadi, Y. M., Mohamad, B., \& Jaafar, M. S. A. (2010). Study of information and communication technology (ICT) usage in technical and vocational special education programme. Global Journal of Human Social Science Research, 10(1), 35-43. Retrieved from https:// globaljournals.org/GJHSS_Volume10/g hss_vol10_issue1_ver1_paper11.pdf

Ahmad, I. (2018). Proses pembelajaran digital dalam era revolusi industri 4.0. Medan: Direktur Jenderal Pembelajaran dan Kemahasiswaan, Kementerian Riset, Teknologi, dan Perguruan Tinggi.

Bhamidipaty, A., Lotlikar, R., \& Banavar, G. (2007). RMI: A framework for modeling and evaluating the resiliency maturity of IT service organizations. In IEEE International Conference on Services Computing (SCC 2007) (pp. 300-307). Salt Like City, UT: IEEE.

Carcary, M. (2013). IT risk management: A capability maturity model perspective. Electronic Journal of Information Systems Evaluation, 16(1), 3-13. 
Retrieved from http://www.ejise.com/ issue/download.html?idArticle $=858$

Deebom, T. M., \& Zite, B. N. (2016). Effectiveness of Information Communication Technology (ICT) in teaching and learning in public senior secondary schools in Ogoni area, Rivers State. International Journal of Education and Evaluation, 2(4), 18-26.

Eady, M., \& Lockyer, L. (2013). Tools for learning: Technology and teaching strategies. In Learning to teach in the primary school (p. 71). Queensland: Queensland University of Technology.

Elmunsyah, H. (2014). A national education policy-based ICT model for Indonesian vocational high schools (VHS). Global Journal of Engineering Education, 16(3), 136-140. Retrieved from http://www.wiete.com.au/journals/GJE E/Publish/vol16no3/06-ElmunsyahH.pdf

Ghavifekr, S., \& Rosdy, W. A. W. (2015). Teaching and learning with technology: Effectiveness of ICT integration in schools. International Journal of Research in Education and Science, l(2), 175. https://doi.org/10.21890/ijres. 23596

Hanum, N. S. (2013). Keefetifan e-learning sebagai media pembelajaran (studi evaluasi model pembelajaran e-learning SMK Telkom Sandhy Putra Purwokerto). Jurnal Pendidikan Vokasi, 3(1), 90-102. https://doi.org/10.21831/ jpv.v3i1.1584

Husain, C. (2014). Pemanfaatan teknologi informasi dan komunikasi dalam pembelajaran di SMA Muhammadiyah Tarakan. Jurnal Kebijakan Dan Pengembangan Pendidikan, 2(2), 184192. Retrieved from http://ejournal. umm.ac.id/index.php/jmkpp/article/vie $\mathrm{w} / 1917 / 2022$

Kumta, G. A., \& Shah, M. D. (2002). Capability maturity model: A human perspective. Delhi Business Review, 3(1). Retrieved from https://pdfs. semanticscholar.org/0620/53d5196644f 84e89876f226a1c639b7d9437.pdf
Lamanauskas, V. (2008). Effective ICT implementation as a precondition for developing general and vocational education. Problems of Education in the 21st Century, 5, 5-8. Retrieved from http://oaji.net/articles/2014/457-13922 23337.pdf

Mas'ud, H., \& Surjono, H. D. (2018). The implementation of flipped classroom learning model using moodle to increase students' higher order thinking skills. Journal of Educational Science and Technology (EST), 1(1), 187-194. https://doi.org/10.26858/est.v1i1.6521

Rahim, M. Y. (2016). Pemanfaatan ICT sebagai media pembelajaran dan informasi pada UIN Alauddin Makassar. Sulesana: Jurnal Wawasan Keislaman, 6(2), 127-135. https://doi.org/10.24252/ .v6i2.1408

Regulation of the Minister of National Education No. 19 of 2005, on National Standard of Education (2005). Republic of Indonesia.

Rusman, R., Kurniawan, D., \& Riyana, C. (2011). Pembelajaran berbasis teknologi informasi dan komunikasi: Mengembangkan profesionalitas guru. Bandung: Rajawali Pers.

Sangrà, A., \& González-Sanmamed, M. (2010). The role of information and communication technologies in improving teaching and learning processes in primary and secondary schools. ALT-J, 18(3), 207-220. https:// doi.org/10.1080/09687769.2010.52910 8

Sujoko, S. (2013). Pemanfaatan teknologi informasi dan komunikasi sebagai media pembelajaran di SMP Negeri 1 Geger Madiun. Jurnal Kebijakan Dan Pengembangan Pendidikan, 1(1), 7177. Retrieved from http://ejournal.umm. ac.id/index.php/jmkpp/article/view/151 1

Supiandi, M. I., \& Lisa, Y. (2018). The utilization of information and communication technology (ICT) on learning in the 21st century. International Journal of Academic Research and Development, 3(2), 869- 
875. Retrieved from http://www. academicjournal.in/download/1762/3-227-207.pdf

Vernanda, D., Abdullah, A. G., \& Rohendi, D. (2018). Internet literacy of vocational high school teachers. IOP Conference Series: Materials Science and
Engineering, 306(1), 12032. https://doi. org/10.1088/1757-899X/306/1/012032

Yasak, Z., \& Alias, M. (2015). ICT integrations in TVET: Is it up to expectations? Procedia-Social and Behavioral Sciences, 204, 88-97. https: //doi.org/10.1016/j.sbspro.2015.08.120 